\title{
Disposable immunosensor for the determination of domoic acid in shellfish
}

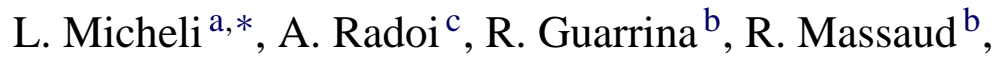 \\ C. Bala ${ }^{\mathrm{c}}$, D. Moscone ${ }^{\mathrm{a}}$, G. Palleschi ${ }^{\mathrm{a}}$ \\ a Dipartimento di Scienze e Tecnologie Chimiche, Università "Tor Vergata”, Via della Ricerca Scientifica, 00133 Rome, Italy \\ b Dipartimento di Medicina Interna, Università "Tor Vergata", Via di Tor Vergata n. 135, 00133 Rome, Italy \\ ${ }^{\mathrm{c}}$ Catedra de Chimie Analitica, Universitatea din Bucuresti, Blvd. Regina Elisabeta, 4-12-703461 Bucharest, Romania
}

Received 17 September 2003; received in revised form 7 January 2004; accepted 7 January 2004

Available online 30 April 2004

\begin{abstract}
The construction of an electrochemical immunosensor coupled to differential pulse voltammetry (DPV) for the detection of domoic acid (DA), a neurotoxic aminoacid responsible for the human syndrome known as "Amnesic Shellfish Poisoning" (ASP), is proposed here.

The method involves the use of disposable screen-printed electrodes (SPEs) for the immunosensor development based on a "competitive indirect test". Domoic acid conjugated to bovine serum albumin (BSA-DA) was coated onto the working electrode of the SPE, followed by incubation with sample (or standard toxin) and anti-DA antibody. An anti-goat IgG-alkaline phosphatase (AP) conjugate was used for signal generation. A spectrophotometric enzyme-linked immunosorbent assay (ELISA) was used in a preliminary phase of development, prior to transferring the assay to the SPEs.

Results showed a detection limit equal to $5 \mathrm{ng} / \mathrm{ml}$ of toxin. The electrochemical system is simple and cost-effective due to the disposable nature of the SPEs, and the analysis time is $150 \mathrm{~min}$, shorter than that for the spectrophotometric method.

The suitability of the assay for DA quantification in mussels was also evaluated. Samples were spiked with DA before and after the sample treatment to study the extraction efficiency and the matrix effect, respectively. After treatment, samples were analysed using a 1:250 v/v dilution in PBS-M (phosphate saline buffer $\mathrm{pH} 7.4+\mathrm{CH}_{3} \mathrm{OH} 10 \%$ ) to minimise the matrix effect and allow for the detection of $20 \mu \mathrm{g} / \mathrm{g}$ of DA in mussel tissue. This represents the maximum acceptable limit defined by the Food and Drug Administration [Compliance Programme 7303.842. Guidance Levels, Table 3, p. 248, http://www.fda.org].

The optimised ELISA systems were then used, in parallel with a conventional HPLC method, to detect and confirm DA in shellfish extract in order to verify the performance of the electrochemical system. Very good recoveries were obtained, demonstrating the suitability of the proposed assay for accurate determination of the DA concentration in mussel samples.
\end{abstract}

(C) 2004 Elsevier B.V. All rights reserved.

Keywords: Enzyme immunoassay; Domoic acid; Amnesic shellfish poisoning; Screen-printed electrodes

\section{Introduction}

Domoic acid (DA) was originally isolated from Chondria armata, which is locally known in Japan as "domoi", and is the antihelminthic agent in a long used traditional medicine. It was later identified as the cause of a shellfish-poisoning syndrome, Amnesic Shellfish Poisoning (ASP), which was first observed on Prince Edward Island in Canada. The source of the toxin was shown to be the diatom

\footnotetext{
* Corresponding author.

E-mail address: laura.micheli@uniroma2.it (L. Micheli).
}

Pseudo-nitzschia pungens forma multiseries (Urieling et al., 1996; Pan et al., 2001). Domoic acid can enter the marine food chain via molluscan shellfish, such as mussels, that filter their food out of water which can contain diatoms. The toxin accumulates in the digestive gland and certain other shellfish tissue. It appears to have no effect on these animals.

In order to protect consumers from ASP, most countries have set a regulatory upper limit for DA in shellfish of $20 \mu \mathrm{g} / \mathrm{g}(20 \mathrm{ppm})$ in accordance with recommendations of Inverson and Truelove, 1994.

At present, high performance liquid chromatography (HPLC) coupled with UV detection is the standard AOAC 


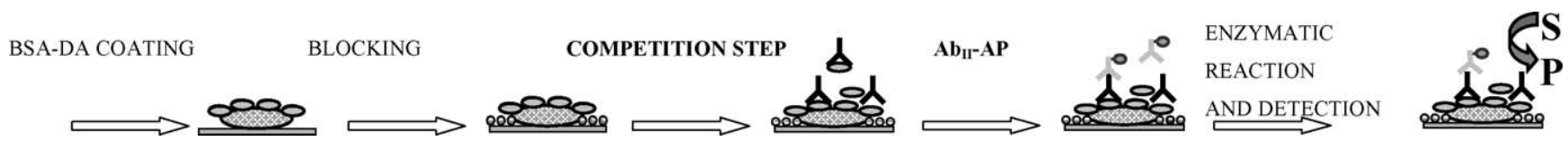

Scheme 1.

method and is widely employed for the monitoring of DA. Although this technique provides good accuracy and reproducibility, it is ill-suited for rapid screening of samples, since it requires time-consuming sample preparation prior to analysis (Kawatsu et al., 1999; Cunniff, 1995). DA is probably one of the most easily detected toxins because of its strong UV chromophore absorbance, but its inherent instability has caused problems. This instability is due to oxidation of the conjugated double bounds (Eilers et al., 1996). There is thus a need for a rapid, selective and sensitive method of DA analysis.

Of the methods of ASP analysis currently available, it seems only enzyme-linked immunosorbent assay (ELISA) with its simple format deserves consideration as a screening and quantitation method for DA.

The current work focuses on the development of a disposable electrochemical immunosensor for the detection of DA in mussel tissue using a polyclonal antibody produced by Toxicology and Food Safety Research (New Zealand) (Garthwaite et al., 1998). Spectrophotometric ELISA was primarily used as a development tool, prior to transfer of the DA assay onto screen-printed electrodes (SPEs). The assay was performed in a competitive scheme (Scheme 1). A bovine serum albumin (BSA) conjugate, BSA-DA, was the basis for the toxin immobilisation procedure. After the competition step, the amount of anti-DA antibody $\left(P A b_{I}\right)$ that reacted with the immobilised DA was evaluated using a secondary alkaline phosphatase (AP) labelled antibody $\left(A b_{I I}-A P\right)$. The detection of this marker was in turn accomplished by use of differential pulse voltammetry (DPV) measuring the electroactive product after addition of the enzyme substrate, 1-naphthyl phosphate (1-NPP).

\section{Reagents and materials}

Polystyrene microtitre plates, MaxiSorp ${ }^{\mathrm{TM}}$, were purchased from NUNC ${ }^{\mathrm{TM}}$ (Roskilde, Denmark). The National Research Centre (NS, Canada) supplied domoic acid calibration solution (DACS-1C) and the BCR reference material containing domoic acid (MUS-1) was purchased from the Institute for Reference Materials and Measurements (IRMM, Belgium). Affinity purified anti-goat $\mathrm{IgG}(\mathrm{H}+\mathrm{L}$, from mouse) alkaline phosphatase conjugate, polyvinyl alcohol (PVA) and all other reagents were from Sigma (St Louis, MO, USA). 4-nitrophenyl (4-NPP) and 1-naphthyl phosphate (1-NPP) were obtained from Fluka Chemie (Sigma-Aldrich, Milan, Italy). Bovine serum albumin conjugated with DA (BSA-DA) and the polyclonal antibodies against DA ( $\mathrm{PAb}_{\mathrm{I}}$ from sheep) were kindly provided by Toxicology and Food Safety Research (AgResearch LimitedNew Zealand). Domoic acid, used to prepare the standards and the spiked samples, was from Biomol (Plymouth Meeting, USA). Mussel samples were obtained from local supermarkets. Single use syringe filters were purchased from Sartorius AG. Screen-printed electrodes were purchased from Prof. M. Mascini (Department of Chemistry, University of Florence, Sesto Fiorentino, Italy). Graphite working electrode with silver reference and counter electrodes formed the three electrode system used.

\subsection{Apparatus}

A model 550-Microplate Reader (Bio-Rad, purchased from Life Science, Italy) was used to read the absorbance on ELISA plates at $405 \mathrm{~nm}$.

The HPLC instrument system consisted of one modular CHROMQUEST Spectra SYSTEM from THERMOQUEST (San Jose, CA, USA) with UV-Vis detector (UV 6000 LP), VACUUM SCM 1000 as degassing unit and an autosampler, AS 3500. A SN 4000 controller operated the HPLC system working under software supervision from the CHROMQUEST module. The HPLC column was a RESTEK Pinnacle II $^{\mathrm{TM}}$ (C18, $5 \mu \mathrm{m}$ spherical particle size).

All electrochemical measurements were performed using a computer-controlled system, AUTOLAB model PGSTAT 12 with GPES software (ECO-CHEMIE, The Netherlands).

\subsection{Buffer solutions}

$1 \mathrm{M}$ diethanolamine buffer (DEA) $\mathrm{pH}$ 9.6, $1 \mathrm{mM} \mathrm{MgCl}_{2}$ was used as the enzymatic substrate buffer for the electrochemical and spectrophotometric measurements.

A $0.1 \mathrm{M}$ carbonate buffer (CB), $\mathrm{pH}$ 9.6, was used for the immobilisation of the antigen on both microplates and electrodes. Polyvinyl alcohol (PVA) solution 1\% (v/v) in carbonate buffer was used as blocking reagent. Phosphate saline buffer (PBS, $15 \mathrm{mM}$ ), pH 7.4, with 10\% $\mathrm{CH}_{3} \mathrm{OH}$ (PBS-M) was used for the competition step. PBS alone was used for the addition of the secondary antibody conjugated with AP $\left(A b_{I I}-A P\right)$. The washing solutions, used after each assay step, were prepared by adding $0.05 \%$ Tween 20 (v/v) to the PBS (PBS-T).

\subsection{Procedure for spectrophotometric ELISA}

All the work is characterised by competitive enzyme immunoassays in microplates with spectrophotometric 
detection used in the development phase prior to analysis by SPE. The indirect ELISA was performed according to Garthwaite et al. (1998), by coating the microplate with BSA-DA conjugate $(2.5 \mu \mathrm{g} / \mathrm{ml}, 50 \mu \mathrm{l}$ per well $)$ in $\mathrm{CB}, \mathrm{pH}$ 9.6, overnight at room temperature. After a washing step with PBS-T ( 2 times, $200 \mu \mathrm{l}$ ) and followed by PBS alone (1 time, $200 \mu \mathrm{l})$, the blocking reagent (1\% PVA in CB) was added to the wells and left for $1 \mathrm{~h}$ at room temperature. The wells were then washed again. For the competition step, a fixed concentration of PAb $(1: 250 \mathrm{v} / \mathrm{v}, 20 \mu \mathrm{l})$ was added to each well in the presence of varying concentrations of DA in PBS-M $(20 \mu \mathrm{l})$. The competition reaction was allowed to proceed for $1 \mathrm{~h}$ at room temperature.

$\mathrm{Ab}_{\mathrm{II}}-\mathrm{AP}(1: 1000 \mathrm{v} / \mathrm{v}, 50 \mu \mathrm{l})$ was then added to wells and incubated for $1 \mathrm{~h}$ at room temperature. Following another washing step, the colorimetric reaction was initiated by addition of substrate solution $(1 \mathrm{mg} / \mathrm{ml} 4-\mathrm{NPP}, 50 \mu \mathrm{l})$ to each well.

\subsection{Procedure for immunosensor}

Immunoassays were performed on the carbon-working surface of an SPE, which was modified in order to obtain a device to react with specificity and selectivity towards analyte.

The working electrode was coated with $7 \mu \mathrm{l}$ of $0.1 \mathrm{M} \mathrm{CB}$, $\mathrm{pH} 9.6$, containing BSA-DA conjugate $(30 \mu \mathrm{g} / \mathrm{ml})$ and incubated for $1 \mathrm{~h}$ at room temperature. After washing with $160 \mu \mathrm{l}$ PBS-T ( $2 \mathrm{~min}$ ) and then $160 \mu \mathrm{l}$ of PBS ( 2 times, $2 \mathrm{~min})$, the electrode was treated with blocking reagent (1\% PVA in CB) for $30 \mathrm{~min}$ at room temperature.

Competition reactions involved the addition a PBS-M solution with a fixed concentration of $\mathrm{PAb}_{\mathrm{I}}(1: 500 \mathrm{v} / \mathrm{v})$ and with various concentrations of DA standard for $30 \mathrm{~min}$ at room temperature. After the washing step, the $A b_{I I}-A P$ $(1: 1000 \mathrm{v} / \mathrm{v}, 6 \mu \mathrm{l})$ was incubated on the working electrode for $15 \mathrm{~min}$. After another washing step, the enzymatic reaction was performed by addition of the substrate solution $(80 \mu 1)$ to each electrode.

Differential pulse voltammetry was the electrochemical technique used to measure the analytical signal (potential range: $0-600 \mathrm{mV}$, scan rate: $300 \mathrm{mV} / \mathrm{s}$, pulse amplitude: $70 \mathrm{mV}$, pulse width: $50 \mathrm{~ms}$ ). No stirring is needed during the measurement: $80 \mu \mathrm{l}$ of solution containing the enzymatic substrate (1-NPP, $1 \mathrm{mg} / \mathrm{ml}$ in DEA buffer) was applied on the sensor surface. After 2 min of incubation time, the DPV was started, and the resulting current recorded.

\subsection{HPLC analysis}

Separation and chromatographic analysis were performed according to the recommended instructions given in MUS-1 Certified Reference Material (Mussel Tissue Reference Material for Domoic Acid, NRC-CNRC, Canada). The mobile phase was aqueous acetonitril with $0.1 \% \mathrm{v} / \mathrm{v}$ trifluoroacetic acid and flow rate was $0.7 \mathrm{ml} / \mathrm{min}$. Detection was accomplished by monitoring absorbance at $242 \mathrm{~nm}$ with a $10 \mathrm{~nm}$ bandwidth. Quantitation was accomplished by comparing the areas of peaks from extracts with those from a dilution series of the DACS- 1 calibration solution. The calibration curve for domoic acid was linear over 3 orders of magnitude. Reproducibility of this external calibration procedure was $2 \%$ R.S.D. for repeated analysis of a single extract.

This analytical method was used to analyse mussel samples for comparison with ELISA results.

\subsection{Sample preparation}

Sample extraction was performed according to the Canadian Food Inspection Agency (Anon., 2004b) guidelines. Mussels were removed from their shells, washed with water and homogenised. Aliquots $(2 \mathrm{~g})$ were weighed in a $15 \mathrm{ml}$ plastic vial and $\mathrm{CH}_{3} \mathrm{OH}: \mathrm{H}_{2} \mathrm{O}(3: 1 \mathrm{v} / \mathrm{v})$ solution was added in order to reach a final volume of $10 \mathrm{ml}$. The $\mathrm{pH}$ was adjusted to 3-3.5. After mixing for $1 \mathrm{~min}$, the mixture was centrifuged at $630 \mathrm{rad} / \mathrm{s}$ for $15 \mathrm{~min}$, in order to remove tissue and extract the toxin. Then the supernatant was filtered through a $0.45 \mu \mathrm{m}$ syringe filter and analysed. For spectrophotometric and electrochemical ELISA tests, the filtered supernatant was diluted 1:250 v/v in buffer (PBS-M) and used directly for the assay.

For HPLC analysis the samples were used as obtained after the filtration step without dilution.

\subsection{Artificial contamination of mussel tissue}

Several dilutions of domoic acid were added to each gram of homogenised tissue in order to obtain the desired concentration. For example, $0.08 \mu \mathrm{g} / \mathrm{ml}$ of DA, when determined in an assay of a 1:250 v/v dilution of tissue extract would correspond to $20 \mu \mathrm{g} / \mathrm{g}$ of tissue. This is currently the maximum level permitted by regulations for commercial mussels (Anon., 2004a). Contaminated homogenates were stored at $-20^{\circ} \mathrm{C}$ or used directly for testing.

\subsection{Calibration plots and analysis of samples}

Standard curves were obtained using DA standard solutions $(0.05-3000 \mathrm{ng} / \mathrm{ml})$ for spectrophotometric and electrochemical ELISA and (0.05-100 ng/ml) for liquid chromatography prepared in PBS-M.

For ELISA, the calibration curves (absorbance at $450 \mathrm{~nm}$ or current versus competitor concentration) were fitted using "non-linear 4 parameter logistic calibration plots" (Warwick, 1996). The four parameter logistic function is:

$f(x)=\left\{\frac{1-a}{1+(x / c)^{b}}\right\}+d$

The parameters $a$ and $d$ are the asymptotic maximum and minimum values, respectively; $c$ is the value at the inflection point $\left(\mathrm{IC}_{50}\right)$ and $b$ is the slope. 
To allow the direct comparison of calibration curves, absorbance values were converted into their corresponding test inhibition values $\left((\% A) / A_{0}\right)$ as follow:

$$
\frac{\% A}{A_{0}}=100\left(\frac{A-A_{\text {sat }}}{A_{0}-A_{\text {sat }}}\right)
$$

where $A$ is the absorbance value of competitors, $A_{\text {sat }}$ and $A_{0}$ are the absorbance values corresponding to the saturating and the non-competition analyte, respectively (as evaluated by the four parameters logistic function).

The detection limit (LOD) was defined as the decrease of the maximum signal equal three times the value of the standard deviations ( $A_{0}-3$ S.D.), measured in the absence of DA ( $A_{0}$, no competition point). The midpoint value $\left(\mathrm{IC}_{50}\right)$ was evaluated as the concentration of DA at $50 \% A / A_{0}$. The working range was evaluated as the toxin concentration that gives test inhibition values of $90 \%$ and $10 \%$ of $A / A_{0}$ (Giraudi et al., 1999).

The matrix effect of blank samples was tested. Different dilutions $(0,1: 10,1: 50,1: 100,1: 250,1: 500,1: 1000 \mathrm{v} / \mathrm{v})$ in PBS pH 7.4 of mussel blank tissue extracts were fortified with DA standard solutions.

In order to evaluate the extraction efficiency, calibration curves in mussels (40-2.5 $\mu \mathrm{g} / \mathrm{g})$, prepared by spiking tissue blank with DA standard solutions before extraction, were performed. The extraction was carried out as reported in the sample extraction procedure. Each experiment was performed in triplicate and the mean of each determination was used for curve fitting.

The data obtained for each curve were plotted and fitted using a SigmaPlot software (SPSS). Regression analysis on the linear portion of the sigmoidal curves was also performed.
Validation samples $(40,20,10 \mu \mathrm{g} / \mathrm{g}$ of tissue), used to evaluate the accuracy and the precision of the methods, were prepared in the same way as for the calibration curves. These concentrations were chosen because they correspond to the regulatory limit $(20 \mu \mathrm{g} / \mathrm{g})$, one-half $(10 \mu \mathrm{g} / \mathrm{g})$ and two-fold $(40 \mu \mathrm{g} / \mathrm{g})$. Confirmation of the ELISA results was obtained by analysing the same extracts using a previously validated HPLC method (Cunniff, 1995).

In addition reference material (MUS- $1 ; 98 \pm 5 \mu \mathrm{g}$ of mussel tissue per gram of DA) supplied by the IRMM (Belgium) was analysed. The extraction was done as reported above in the extraction procedure. Each experiment was performed in six replicates and mean values were use for curve fitting.

\section{Results}

\subsection{Optimisation of ELISA parameters}

Optimisation of ELISA parameters such as temperature, buffer, and amount of antibody, was initially performed for the spectrophotometric and electrochemical systems using standard solutions of the analyte under investigation. The spectrophotometric protocol used was similar to that of Garthwaite (Garthwaite et al., 1998), with minor modification, such as the blocking reagent (1\% PVA in coating buffer), the competition buffer (PBS $+10 \% \mathrm{CH}_{3} \mathrm{OH}$ ), and the amount of specific antibody to use during competition. The optimised curve is shown in Fig. 1. After fitting the standard curves for DA using the "non linear four parameter logistic calibration plots", the working range (Giraudi et al., 1999) was determined to be $0.2-50 \mathrm{ng} / \mathrm{ml}$; the detection limit, $0.6 \mathrm{ng} / \mathrm{ml}$ of DA.

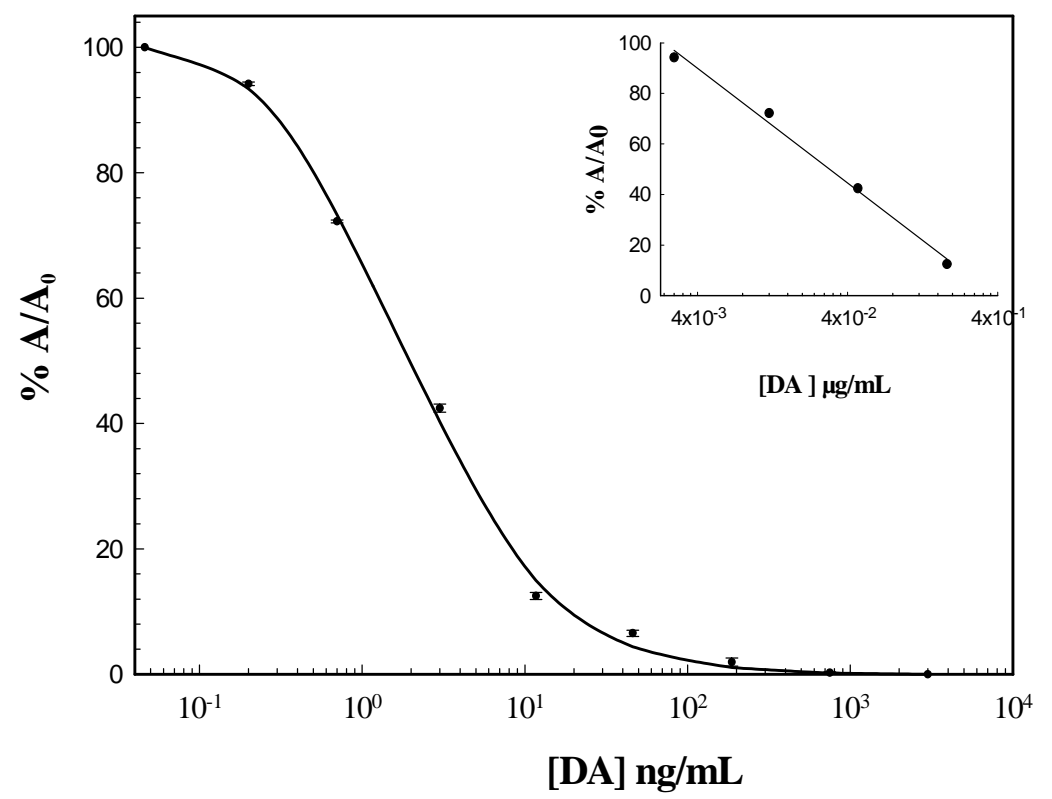

Fig. 1. The indirect competitive ELISA for domoic acid. BSA-DA $(2.5 \mu \mathrm{g} / \mathrm{ml})$ was coated on the ELISA plate and antibody against DA 0was used as competitor. Linear regression shows a working range of $0.2-50 \mathrm{ng} / \mathrm{ml}$. 


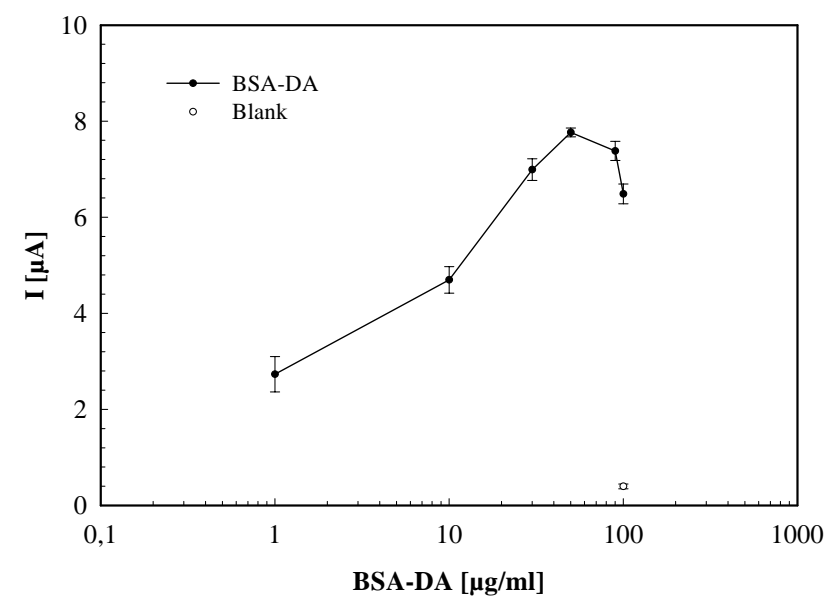

Fig. 2. Coating study. Several dilutions of BSA-DA $(1-100 \mu \mathrm{g} / \mathrm{ml})$ were coated on SPEs and fixed amount of primary antibody $(1: 250 \mathrm{v} / \mathrm{v})$ and secondary Ab labelled with enzyme $\left(\mathrm{Ab}_{\mathrm{II}}-\mathrm{AP} 1: 1000 \mathrm{v} / \mathrm{v}\right)$ were used. The BSA-DA concentration chosen was $30 \mu \mathrm{g} / \mathrm{ml}$. Blank: no coating, [Pab] $1: 250 \mathrm{v} / \mathrm{v}, \mathrm{Ab}_{\text {II }}-\mathrm{AP} 1: 1000 \mathrm{v} / \mathrm{v}$.

For the electrochemical studies, chessboard titrations were performed on electrodes to assess the optimum concentration and time of each step. The first step was the optimisation of the limiting amount of available primary antibody against $\mathrm{DA}\left(\mathrm{PAb}_{\mathrm{I}}\right)$. This is an important point in developing a competitive test, because the quantity of the antibody must be sufficient to saturate the antigen present on the solid phase. This concentration was identified as 1:500 v/v dilution of $\mathrm{PAb}_{\mathrm{I}}$.

The resulting choices were $30 \mu \mathrm{g} / \mathrm{ml}$ of DA-BSA conjugate (Fig. 2) for $1 \mathrm{~h}$ at room temperature for the coating step, and $1: 1000 \mathrm{v} / \mathrm{v}$ of the $A b_{I I}-A P$ solution for $15 \mathrm{~min}$ at room temperature (Fig. 3). The dilution of $\mathrm{Ab}_{\mathrm{II}}$-enzyme to use was chosen on the basis of adequate signal production (ca. $1 \mu \mathrm{A}$ ). A typical competition curve for DA can be seen in Fig. 4.

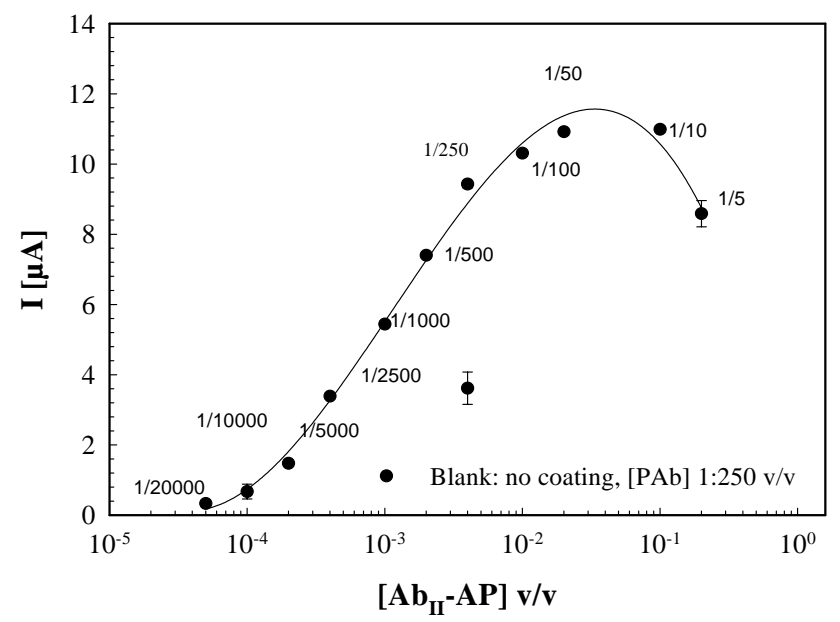

Fig. 3. Optimisation of the $A b_{I I}-A P$ concentration. BSA-DA $(30 \mu \mathrm{g} / \mathrm{ml})$ and $\mathrm{Ab}_{\mathrm{I}}(1: 250 \mathrm{v} / \mathrm{v})$ were immobilised on SPEs and different amounts of $\mathrm{Ab}_{\mathrm{II}}-\mathrm{AP}(1: 20000-1: 5 \mathrm{v} / \mathrm{v})$ were tested. The $\mathrm{Ab}_{\mathrm{II}}-\mathrm{AP}$ concentration chosen was $1: 1000 \mathrm{v} / \mathrm{v}$.

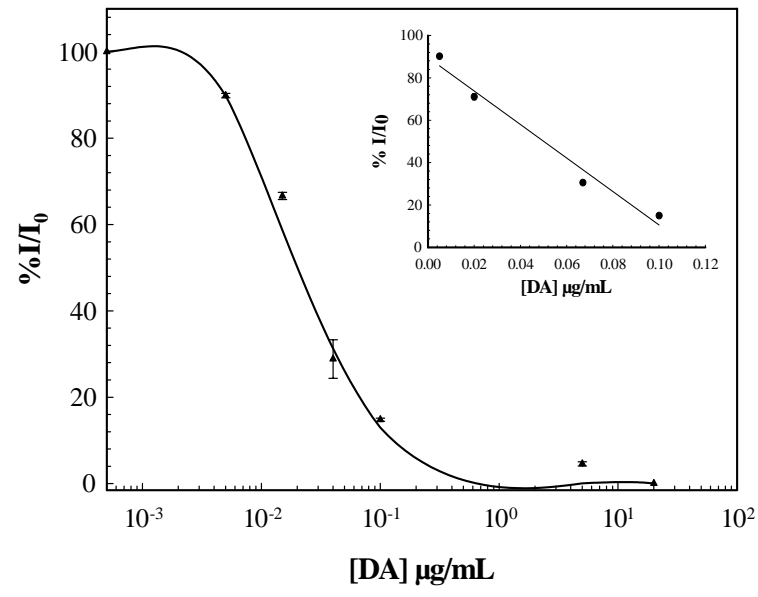

Fig. 4. Indirect competitive ELISA for domoic acid. BSA-DA $(30 \mu \mathrm{g} / \mathrm{ml})$ was coated on the SPEs and antibody against DA was used as competitor. Linear regression shows a working range of $5-100 \mathrm{ng} / \mathrm{ml}$. Electrochemical technique: DPV.

In the case of the developed system, the working range and the LOD were between 5 and $70 \mathrm{ng} / \mathrm{ml}$ and around $5 \mathrm{ng} / \mathrm{ml}$, respectively, calculated as for the spectrophotometric system. The intraelectrode reproducibility (expressed as \%R.S.D.) was $6.6 \%$ for a concentration of $20 \mu \mathrm{g} / \mathrm{g}$ $(n=30)$.

\subsection{Stability}

The stability of coating reagents was evaluated using SPEs coated with conjugated antigen, then blocked and stored at $4{ }^{\circ} \mathrm{C}$.

A parallel investigation was done treating the electrodes with $5 \mu \mathrm{l}$ of ProClin 200 (Supelco) for $30 \mathrm{~min}$ at room temperature, after the coating step. They were then washed and stored at $4{ }^{\circ} \mathrm{C}$. The ProClin preservative is known to be a highly effective biocide agent for inhibiting growth of microorganisms in biological media. It is also compatible with most enzyme systems and does not inhibit antibody binding. Assays were performed periodically using the assessed protocol.

Results showed that the electrodes treated with preservative could be used for up to 4 weeks after the coating step, while the ones without preservative were stable for about 15 days (Fig. 5).

\subsection{Measurements of DA in mussels}

The spectrophotometric and electrochemical ELISA assays were then applied to mussel tissue to test their performance in a real matrix. Mussel samples were collected and the extraction procedure performed as described in the experimental section in order to evaluate matrix effect and extraction efficiency.

The matrix effect was characterised using mussel samples in which there was no toxin present (mussel tissue 


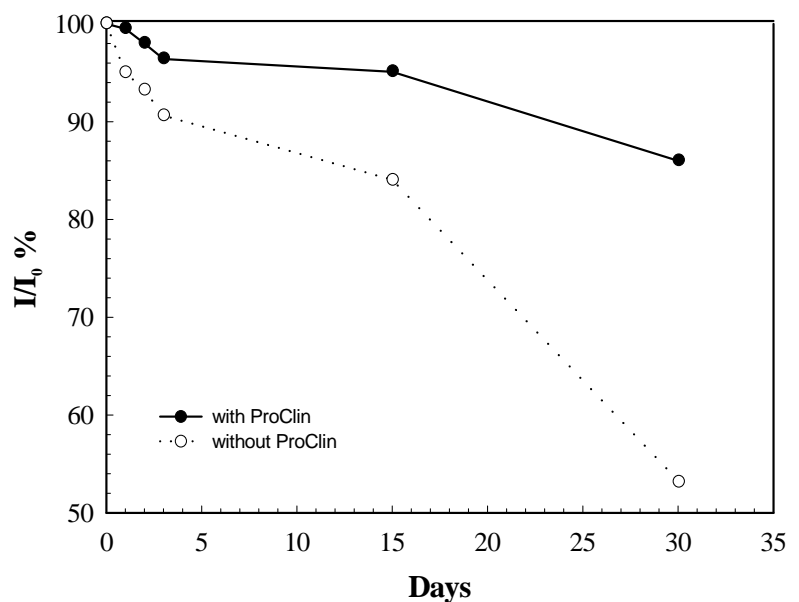

Fig. 5. Stability studies. Parallel investigation for electrodes treated with ProClin preservative $(\mathbf{O})$ and non-treated $(\mathrm{O})$ electrodes.

blanks). The standard curve for DA diluted in PBS-M ( $\mathbf{\nabla})$ was compared with the calibration curves obtained using different dilution $(0,1: 10,1: 100,1: 250,1: 1000,1: 10000$ $\mathrm{v} / \mathrm{v})$ of mussel samples spiked after the extraction with know amount of the toxin solutions. For spectrophotometric ELISA, the lowest matrix effect $(\boldsymbol{\Lambda})$ was observed when the matrix dilution 1:250 v/v was used (Fig. 6a). Similar results were obtained for the electrochemical method (Fig. 6b). Moreover, this dilution enabled detection of the maximum permitted level of $20 \mu \mathrm{g}$ of DA/g of mussels. Considering the sample extraction procedure and the dilution, this amount of the toxin in mussel corresponded to $0.08 \mu \mathrm{g} / \mathrm{ml}$ of DA on the calibration curve. For both systems, a linear range between 5 and $70 \mathrm{ng} / \mathrm{ml}$ was observed. The regression analysis performed in this range showed that the SPE assay $\left(r^{2}=0.975\right)$ gave better results than the microplate one $\left(r^{2}=0.952\right)$. The time for each measurement with the electrochemical system was shorter than that with the spectrophotometric assay: 45 min versus $2 \mathrm{~h}$.

Finally, the extraction efficiency was evaluated by a comparison of the calibration curve, constructed by spiking blank mussels with known amounts of DA before extraction (-) with that obtained when the toxin was added to mussel tissue blanks after the extraction $(\boldsymbol{\Lambda})$. For each concentration level, four different samples were independently processed and analysed using eight different SPEs. On the basis of the calibration curves prepared in mussel extract it was possible to calculate the extraction efficiency of the analyte (83-106\% of DA-the value of $83 \%$ is observed for the lowest concentration of the toxin). Comparable results $(87 \pm 7 \%$ of DA) were obtained using the reference material (MUS-1) supplied by the IRMM. To obtain samples falling within our working range, the MUS-1 material was extracted as described above and diluted by a factor of 1:1250 v/v. These results regarding the recovery with this extraction procedure were in agreement with ones reported in the literature (Anon., 2004b).

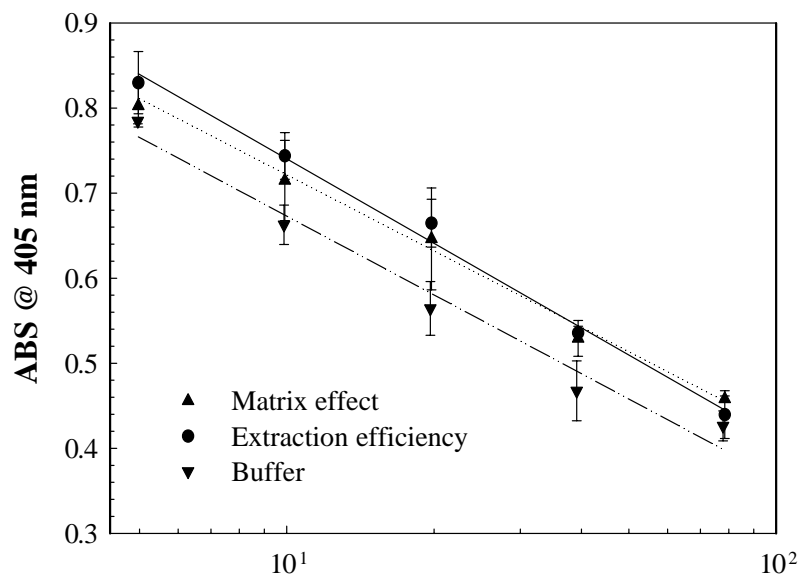

(a)

[DA] ng/mL

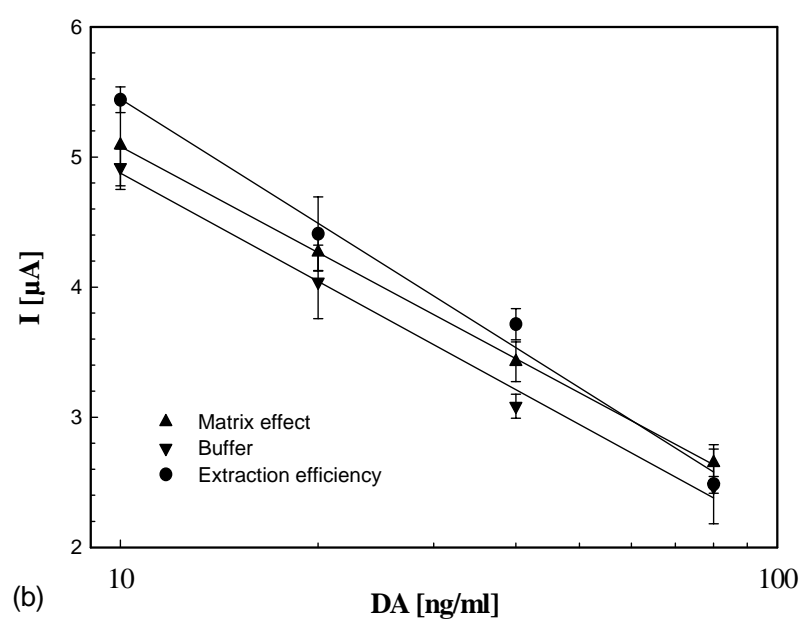

Fig. 6. (a) Spectrophotometric ELISA. Effect of sample treatment and matrix on competitive indirect ELISA for DA. Calibration curves, obtained by spiking mussel samples, with known amounts of DA before $(\boldsymbol{\Lambda})$ and after (-) extraction. Results were compared to the calibration curves obtained in buffer $(\boldsymbol{\nabla})$. In all three cases the extracts were diluted 1:250 w/v and assayed. (b) Electrochemical ELISA. Effect of sample treatment and matrix on competitive indirect ELISA for DA. Calibration curves, obtained by spiking mussel samples, with known amounts of DA before $(\boldsymbol{\Delta})$ and after (O) extraction. Results were compared to the calibration curves obtained in buffer $(\boldsymbol{\nabla})$. In all three cases the extracts were diluted $1: 250 \mathrm{w} / \mathrm{v}$ and assayed.

Repeatability of ELISA assays were evaluated by means of six replicate determination on tissue from mussels bought in different days and stores. Control sample blanks fortified with DA at concentrations equal to the regulatory limit $(20 \mu / \mathrm{g}$ equal to $0.08 \mu \mathrm{g} / \mathrm{ml}$ on the calibration curve), to one-half $(10 \mu \mathrm{g} / \mathrm{g}$ equal to $0.04 \mu \mathrm{g} / \mathrm{ml})$ and to two-fold ( $40 \mu \mathrm{g} / \mathrm{g}$ equal to $0.16 \mu \mathrm{g} / \mathrm{ml})$, were prepared and analysed on each of four different days for each concentration $(n=$ 16 for each level). The precision was determined by calculating the relative standard deviation (R.S.D.) for the replicate measurements and the accuracy (\%R.E.) was calculated by assessing the agreement between measured and nominal concentration of the fortified samples. In order to evaluate the repeatability and accuracy of the analytical method, six 
Table 1

Validation and certified sample analysis using screening assays and HPLC. Accuracy (\%R.E.) of these techniques vs. HPLC

\begin{tabular}{|c|c|c|c|c|c|c|c|c|c|c|c|}
\hline \multirow{2}{*}{$\begin{array}{l}\text { Standard } \\
\text { DA added } \\
\left(\mu \mathrm{g} \mathrm{g}^{-1}\right)\end{array}$} & \multicolumn{3}{|c|}{ Spectrophotometric ELISA } & \multicolumn{3}{|c|}{ Electrochemical ELISA } & \multicolumn{3}{|l|}{ HPLC } & \multirow{2}{*}{$\begin{array}{l}\text { Spectrophotometric } \\
\text { ELISA/HPLC } \\
\text { \%R.E. }\end{array}$} & \multirow{2}{*}{$\begin{array}{l}\text { Electrochemical } \\
\text { ELISA/HPLC } \\
\text { \%R.E. }\end{array}$} \\
\hline & $\begin{array}{l}\text { DA found } \\
\left(\mu g^{-1}\right)\end{array}$ & $\%$ RSD & $\% \mathrm{RE}$ & $\begin{array}{l}\text { DA found } \\
\left(\mu g g^{-1}\right)\end{array}$ & \%R.S.D. & \%R.E. & $\begin{array}{l}\text { DA found } \\
\left(\mu g^{-1}\right)\end{array}$ & \%R.S.D. & \%R.E. & & \\
\hline 40 & 44 & 6 & 10 & 42 & 8 & -5 & 40 & 2 & 0 & 10 & 5 \\
\hline 20 & 20 & 5 & 0 & 17 & 9 & -15 & 17 & 4 & -15 & 18 & 0 \\
\hline 10 & 9 & 4 & -10 & 9 & 6 & -10 & 10 & 1 & 0 & -10 & -10 \\
\hline $\begin{array}{l}\text { Certified } \\
\text { material }^{\mathrm{a}}\end{array}$ & 17 & 8 & -15 & 18 & 5 & -10 & 17 & 2 & -15 & 0 & 6 \\
\hline
\end{tabular}

a The MUS-1 was diluted in order to obtain a final concentration of $20 \mu \mathrm{g}$ of DA per gram of mussel tissue.

replicates of the MUS-1 $(20 \mu \mathrm{g} / \mathrm{g})$ were analysed. Finally to evaluate accuracy, results obtained using the two screening assays were confirmed analysing the same extracted samples by use of a previously validated HPLC method (Cunniff, 1995). Table 1 reports the accuracy of both screening systems versus HPLC for artificially contaminated and certificated mussels.

The reliability of the immunoassays for the determination of the DA in spiked samples was demonstrated by comparison of the data with the fully validated confirmatory HPLC results.

\section{Conclusions}

In this work, a disposable electrochemical enzyme-linked immunosorbent assay for detection of DA was developed using a screen-printed electrode system as transducer for differential pulse voltammetry, with a monoclonal antibody serving for molecular recognition. The conventional methods, spectrophotometric ELISA or HPLC analysis, are both time consuming and do not lend themselves to on-site measurement. We took advantage of the simplicity of the ELISA system to construct a DA immunosensor that was capable of measuring the same levels of toxin as detected by the conventional methods while having the advantages of speed, simplicity of design and the possibility of use in the field with portable instrumentation. In fact, the prepared devices (coated SPEs) can be stored for up to 4 weeks to be ready for "in situ" determination. The sensor exhibited linearity between 5 and $70 \mathrm{ng} / \mathrm{ml}$ with a limit of detection of $5 \mathrm{ng} / \mathrm{ml}$. This detection level is sufficient, given that the maximum acceptable level of DA in mussel is $20 \mu \mathrm{g} / \mathrm{g}$ $(0.08 \mu \mathrm{g} / \mathrm{ml})$. Recovery of DA from spiked mussels was around $83 \pm 6 \%$ for low concentrations, while it increased to $98 \pm 6 \%$ for toxin concentrations higher than of $5 \mu \mathrm{g} / \mathrm{g}$ $(0.02 \mu \mathrm{g} / \mathrm{ml})$. For certified material (MUS-1) the recovery was around $87 \pm 7 \%$ of DA.

In conclusion we have shown that competitive immunoassays for DA is indeed a functional strategy and that the immunosensor realised for this toxin shows a working range that is comparable to that for conventional methods and also have a detection limit suitable for "on-site" monitoring.

\section{Acknowledgements}

This work was supported by the E.C. project CT 96 FAIR 1092 and by the European Concerted Action QLK3 - 200-01311 "Evaluation/Valuation of Novel Biosensors in Real Environmental and Food Samples". We gratefully thank Toxicology and Food Safety Research (AgResearch Limited- New Zealand) for the BSA-DA conjugate and the polyclonal antibodies against DA.

\section{References}

Anon., 2004a. Fish and Fisheries Products Hazards and Contros Guide, cap 6-Natural Toxins (A Chemical Hazard), 2nd Edition, January 1998, http://www.cfsan.fda.gov/ dms/haccp-2f.html.

Anon., 2004b. Fish Products Standards and Methods Manual, http://www.inspection.gc.ca/english/anima/fispoi/guide/chme.shtml.

Cunniff, P., 1995. Official method of analysis of AOAC International. Nat. Toxins 49, 48.

Eilers, P., Conrad, S., Hall, S., 1996. Domoic acid analysis. Toxicon 34 (3), 338.

Garthwaite, I., Ross, K.M., Miles, C.O., Hansen, R.P., Foster, D., Wilkins, A.L., Towers, N., 1998. Polyclonal antibodies to domoic acid and their use in immunoassays for domoic acid in sea water and shellfish. Nat. Toxins 6, 93-104.

Giraudi, G., Rosso, I., Baggiani, C., Giovanoli, C., Vanni, A., Grassi, G., 1999. Development of enzyme linked immunosorbent assay for benalaxyl and its application to the analysis of water and wine. Anal. Chim. Acta 392, 85-94.

Inverson, F., Truelove, J., 1994. Toxicology and seafood toxins: domoic acid. Nat. Toxins 2, 334-339.

Kawatsu, K., Hamano, Y., Noguchi, T., 1999. Production and characterisation of a monoclonal antibody against domoic acid and its application to enzyme immunoassay. Toxin 37, 1579-1589.

Pan, Y., Parsons, M.L., Busman, M., Moeller, P.D.R., Dortch, Q., Powell, C.L., Doucette, G.J., 2001. Pseudo-nitzschia sp. cf Pseudodelicatissima - a confirmed producer of domoic acid from the northern Gulf of Mexico. Marine Ecol. Prog. Ser. 220, 8392.

Urieling, E.G., Koeman, R.P.T., Scholin, C.A., Scheerman, P., Peperzak, L., Veenhuis, M., Gieskes, W.W.C., 1996. Identification of a domoic acid-production Pseudo nitzschia species (Bacillaiaphyceae) in the Dutch Wadden Sea with electron microscopy and molecular species. E. J. Phycol. 31, 333-340.

Warwick, M.J., 1996. cap. 8. Standardisation of immunoassays. In: Brian L. (Ed.), Immunoassay, A Practical Guide. Taylor \& Francis Ltd, UK, pp. $150-170$. 